Pluralitas Indonesia, oleh: Miftahuddin

\title{
PLURALITAS INDONESIA \\ INTEGRASI NASIONAL DAN TANGGAPAN ISLAM
}

\author{
Miftahuddin $^{*}$
}

\begin{abstract}
Abstrak
Masyarakat Indonesia sebagai suatu sistem sosial memiliki struktur sosial yang unik, baik secara vertikal maupun horizontal. Secara vertikal struktur sosial masyarakat Indonesia ditandai perbedaan-perbedaan vertikal antara lapisan atas dan lapisan bawah yang tajam. Secara horizontal, struktur sosial masyarakat Indonesia terdiri atas berbagai suku bangsa, adatistiadat, bahasa serta agama yang mencirikan masyarakat Indonesia sebagai suatu masyarakat majemuk. Hal ini sering menimbulkan berbagai konflik sebagai suatu konsekuensi masyarakat yang majemuk. Artikel ini membahas tentang keragaman Indonesia dan upaya-upaya untuk menjaga integritas nasional. Tanggapan Islam terhadap keragaman ini dibahas di akhir tulisan.
\end{abstract}

Kata Kunci, pluralitas, integrasi nasional, tanggapan Islam

\section{Pluralitas Masyarakat Indonesia}

Indonesia memiliki sejarah yang panjang dari manusia pertama yang menghuni Nusantara ini sampai kelahirannya sebagai negara merdeka yang berdaulat pada 17 Agustus 1945. Sejarah yang panjang itu menyimpan berbagai macam kekayaan yang beragam berupa sumber daya alam dan sumber daya manusia. Keragaman sumber daya manusia Indonesia berupa penduduknya yang bersifat majemuk dan sangat plural, terdiri dari bermacam-macam suku, etnis, ras, agama, sosial, budaya, taraf ekonomi, kedenderungan politik dan sebagainya. Mengenai jumlah suku di Indonesia, terdapat berbagai pendapat dari para peneliti. Hildred Geertz menyebutkan bahwa di Indonesia terdapat

\footnotetext{
* Dosen Institut Agama Islam Tribakti (IAIT) Kediri
} 
Pluralitas Indonesia, oleh: MiftahuddiQ

dari 300 suku. ${ }^{1}$ Sedangkan Skinner, seperti dikutip Nasikun, menyebutkan bahwa di Indonesia terdapat lebih dari 35 suku yang masing-masing mempunyai adat dan bahasa yang berbeda-beda. Ia juga menyebutkan lima suku yang tergolong besar yaitu: Jawa, Sunda, Madura, Minangkabau dan Bugis. ${ }^{2}$

Undang-Undang Dasar 1945 menjamin dan mengakui lima agama untuk tumbuh dan berkembang di Indonesia, yaitu Islam, Katolik, Protestan, Hindu dan Budha. Di luar lima agama resmi tersebut, masih terdapat ideologi dan kepercayaan lain seperti: Konghuchu, aliran kepercayaan, kejawen dan lain-lain. Selain itu, pada masing-masing agama di atas terdapat banyak mazhab yang diikuti oleh para pendukungnya.

Selain itu, Indonesia juga memiliki banyak ragam budaya. Hal itu terlihat dari adapt istiadat, pola hidup, interkasi sosial, bahasa sebagai alat komunikasi dan lain-lain. Beragamnya budaya Indonesia tersebut selain dilatar belakangi oleh suku yang berbeda-beda budaya juga akibat dari pengaruh luar yang diminati oleh penduduknya. Budaya asing dan agama yang masuk sangat berpengaruh terhadap penciptaan budaya baru yang terus tumbuh dan berkembang di Indonesia. Agama Hindu yang datang dari India, agama Islam dari Arab, agama Kristen dari Eropa serta agama Budha dari negara-negara Indocina sangat berpengaruh dalam proses pembentukan budaya di Indonesia sampai sekarang. ${ }^{3}$

Dalam kehidupan politik, kemajemukan bangsa Indonesia terlihat pada kemauan politik masyarakat yang selalu tidak sama. Hal ini antara lain dapat dilihat dari jumlah partai politik yang selalu banyak. Hingga puncaknya terlihat pada pemilihan umum 1999 yang diikuti oleh 48 partai politik. Masing-masing partai politik memiliki platform, visi dan misi yang berdeda dengan lainnya.

Dalam struktur ekonomi, terdapat dua macam sektor yang masing-masing memiliki karakter berbeda. Pertama, ekonomi yang bernilai komersial tinggi, relatif canggih, berhubungan dengan lalu lintas perdagangan internasional, memperoleh keuntungan maksimal

\footnotetext{
${ }^{1}$ Hildred Geertz, Aneka Budaya dan Komunitas di Indonesia (Jakarta: Yayasan Ilmu-ilmu Sosial, 1981),h. 36.

${ }^{2}$ Nasikun, Sistem Sosial Indonesia (Jakarta: Rajawali Press, 1995), h. 36.

${ }^{3}$ Ibid, h. 3 .
} 
Pluralitas Indonesia, oleh: Miftahuddin

dan biasanya banyak dikuasai oleh warga keturunan, khususnya Cina. Kedua, terdapat sistem ekonomi di pedesaan yang bersifat tradisional, didorong oleh motif-motif kepuasan sosial, tidak berorientasi pada keuntungan komersial semata, konservatif dan tidak tergiur dengan lalu lintas perdagangan internasional. ${ }^{4}$

Di satu sisi, kebinekaan itu merupakan kekayaan besar yang dapat menyokong negara ini menjadi sebuah entitas yang kokoh. Namun di sisi lain, kebinekaan itu juga dapat menjadi sumber melapetaka besar yang mengantarkan negara ini menuju jurang kehancuran.

Kajian yang lebih jeli terhadap realitas kemajemukan masyarakat Indonesia akan mengungkap lebih banyak dan lebih rinci mengenai varian-varian yang terdapat di dalamnya. Salah satu contoh adalah penelitian Clifford Geertz di Mojokuto, nama rekaan dari Pare, Kediri, Jawa Timur, yang memakan waktu mulai tahun 1951 sampai 1954. Dalam penelitiannya, dia membagi masyarakat Jawa dalam tiga varian, yaitu: priyayi, santri dan abangan. Ia memberi judul penelitiannya dengan The Religion of Java. ${ }^{5}$

Pierre L. van den Berghe, seperti dikutip Nasikun, menyebutkan karakteristik masyarakat majemuk sebagai berikut:

1. Terjadinya segmentasi ke dalam bentuk kelompok-kelompok yang seringkali memiliki sub-kebudayaan yang berbeda satu sama lain.

2. Memiliki struktur sosial yang terbagi-bagi ke dalam lembagalembaga yang bersifat non-komplementer.

3. Kurang mengembangkan konsensus di antara anggotanya terhadap nilai-nilai yang bersifat dasar.

4. Secara relatif sering mengalami konflik-konflik di antara kelompok yang satu dengan kelompok yang lain.

5. Secara relatif integrasi sosial tumbuh di atas paksaan (coercion) dan saling ketergantungan di dalam bidang ekonomi.

6. Adanya dominasi politik oleh suatu kelompok atas kelompokkelompok yang lain. ${ }^{6}$

\footnotetext{
${ }^{4}$ Ibid, h. 47.

5 Telah diterjemahkan Aswab Mahasin dengan judul, Abangan, Santri, Priyayi Dalam Masyarakat Jawa (Jakarta: Pustaka Jaya, 1989).

${ }^{6}$ Nasikun, Sistem Sosial Indonesia, h. 33.
}

Vol. 22 Nomor. 1 Januari 2011 
Pluralitas Indonesia, oleh: MiftahuddiA

Para sosiolog menjelaskan faktor-faktor yang menyebabkan timbulnya pluralitas di Indonesia. Pertama, keadaan geografis Indonesia yang terdiri dari 13.000 pulau. Letak komunitas penduduk yang terpisah dengan yang lain menyebabkan lahirnya berbagai tradisi, bahasa, model interaksi, gaya hidup, kecenderungan dan sebagainya. Kesatuankesatuan kelompok yang terisolasi dari kelompok yang lain itulah yang akhirnya membentuk suku dan ras yang berbeda-beda. Kedua, kepulauan Indonesia yang terletak di antara samudera Indonesia dan Pasifik menjadikan wilayah ini terbuka untuk jalur perhubungan internasional. Hal ini berakibat pada masuknya pengaruh bangsa dan peradaban asing kepada penduduk Indonesia. Hal ini dapat dilihat dari adanya pluralitas agama di Indonesia. Ketiga, faktor ekologi dan iklim yang berbeda-beda menjadi sebab timbulnya pluralitas regional di Indonesia. Struktur tanah pertanian serta curah hujan yang tidak sama menyebabkan munculnya skstem pertanian yang tidak sama antara beberapa daerah di Indonesia. ${ }^{7}$

\section{Pendekatan Teoretis}

Untuk memahami pluralitas di Indonesia, setidaknya terdapat dua pendekatan, yaitu pendekatan struktural fungsional dan pendekatan konflik. Berikut adalah uraian dari kedua pendekatan ini.

\section{Struktural Fungsional}

Pendekatan ini dicetuskan sosiolog terkemuka, Talcott Parsons. Ia lahir tahun 1902, putra seorang pendeta. Pada masa mudanya, Parsons memberikan perhatiannya pada masalah kedokteran. Namun keterkaitannya pada masalah-masalah sosial-ekonomi mengantarkannya ke London dan Jerman. Pada tahun 1927, Parsons memperoleh gelar doktor dari Universitas Heidelberg dengan disertasi mengenai ilmu sosial di Jerman, khususnya Weber, Werner Sombart dan Marx mengenai kapitalisme. ${ }^{8}$

Anggapan dasar yang menjadi bangunan pendekatan struktural fungsional Parsons dan para pendukungnya seperti yang kutip oleh Nasikun, dapat dirangkum sebagai berikut:

\footnotetext{
${ }^{7}$ Ibid, h. 35

${ }^{8}$ Doyle Paul Johnson, Teori Sosiologi Klasik dan Modern, Jilid 2 (Jakarta: Gramedia Pustaka Utama, 1990), h. 102-103.
} 
Pluralitas Indonesia, oleh: Miftahuddin

a. Masyarakat harus dilihat sebagai suatu sistem yang bagianbagiannya saling berhubungan antara satu dengan lainnya.

b. Hubungan saling mempengaruhi antara bagian-bagian dalam masyarakat bersifat ganda dan timbal balik.

c. Meskipun integrasi sosial tidak pernah dapat tercapai dengan sempurna, namun secara fundamental (prinsip) sistem sosial selalu cenderung bergerak ke arah equilibrium (keseimbangan) yang bersifat dinamis, menanggapi perubahan-perubahan yang datang dari luar dengan kecenderungan memelihara agar perubahanperubahan yang terjadi di dalam sistem sebagai akibatnya hanya akan mencapai derajat yang minimal.

d. Sekalipun disfungsi, ketegangan-ketegangan dan penyimpanganpenyimpangan selalu terjadi, tetapi akhirnya keadaan tersebut akan teratasi dengan sendirinya melalui penyesuaian-penyesuaian dan institusionalisasi. Dengan kata lain, meskipun integrasi sosial secara sempurna tidak akan tercapai, namun setiap sistem sosial akan selalu berproses ke arah itu.

e. Perubahan-perubahan di dalam sistem sosial pada umumnya terjadi secara gradual (perlahan-lahan), melalui penyesuaian-penyesuaian dan tidak secara revolosioner. Perubahan-perubahan secara drastis hanya mengenai bentuk luarnya saja. Sedangkan unsur-unsur sosial budaya yang menjadi bangunan dasarnya tidak seberapa mengalami perubahan.

f. Pada dasarnya, perubahan-perubahan sosial timbul atau terjadi melalui tiga kemungkinan, yaitu: penyesuaian-penyesuaian yang dilakukan oleh sistem sosial tersebut terhadap perubahan-perubahan yang datang dari luar, pertumbuhan melalui proses diferensiasi struktural dan fungsional; serta penemuan-penemuan baru oleh anggota-anggota masyarakat.

g. Faktor paling penting yang memiliki daya mengintegrasikan suatu sistem sosial adalah konsensus (kesepakatan bersama) di antara para anggota masyarakat mengenai nilai-nilai kemasyarakatan tertentu. ${ }^{9}$

Dengan kata lain, sebuah sistem sosial pada dasarnya merupakan sistem tindakan-tindakan. Sistem ini terbentuk melalui interaksi sosial antara individu atas dasar penilaian umum yang telah disepakati bersama oleh para anggota masyarakat. Norma-norma sosial yang telah

\footnotetext{
${ }^{9}$ Nasikun, Sistem Sosial Indonesia, h. 10.
} 
Pluralitas Indonesia, oleh: Miftahuddit

disepakati itulah yang sesungguhnya membentuk struktur sosial. Dalam pandangan struktur fungsional, dalam setiap masyarakat pasti terdapat anggapan atau nilai-nilai dasar tertentu yang disepakati memiliki kebenaran mutlak. Nilai-nilai dasar tersebut mampu menjadi sumber integrasi sosial dan bahkan penyeimbang bagi berlangsungnya sistem tersebut. Pendekatan struktural fungsional bukan tidak menuai kritik. Pendekatan ini dianggap telah mengabaikan, ketegangan-ketegangan dan penyimpangan-penyimpangan sosial yang justru menambah semakin kompleksnya diferensi sosial. ${ }^{10}$

\section{Teori Konflik}

Karl Marx dipandang sebagai tokoh utama dan yang paling kontroversial dalam menjelaskan sumber-sumber konflik serta pengaruhnya terhadap peningkatan perubahan sosial secara revolusioner. Weber melengkapi teori konflik dengan sumbangan pemikirannya bahwa ide-ide agama itu sendiri bisa merupakan sumber konflik. Ia juga menambahkan bahwa ideal-ideal agama dapat membantu melegitimasi posisi sosial dari kelompok yang dominan dalam masyarakat. Sementara Simmel menambahkan bahwa konflik merupakan salah satu bentuk interaksi dan bahwa konflik aktual dan yang potensial secara praktis merembes ke semua bentuk interaksi sosial. ${ }^{11}$

Pandangan pendekatan konflik bertolak pada anggapananggapan dasar yang terangkum sebagai berikut: (1) setiap masyarakat selalu berada dalam proses perubahan yang tidak pernah berakhir, atau dengan kata lain, perubahan sosial merupakan gejala yang melekat dalam setiap masyarakat; (2) setiap masyarakat mengandung konflikkonflik dalam dirinya, atau dengan kata lain konflik merupakan gejala yang melekat dalam setiap masyarakat; (3) setiap unsur dalam suatu masyarakat memberikan sumbangan bagi terjadinya disintegrasi dan perubahan-perubahan sosial; (4) setiap masyarakat terintegrasi di atas penguasaan atau dominasi oleh sejumlah orang atas sejumlah orangorang yang lain. ${ }^{12}$

\footnotetext{
${ }^{10}$ Nasikun, Sistem Sosial Indonesia, h. 13

${ }^{11}$ Doyle Paul Johnson, Teori Sosiologi Klasik dan Modern, h. 163.

${ }^{12}$ Nasikun, Sistem Sosial Indonesia, h. 16.
} 
Pluralitas Indonesia, oleh: Miftahuddin

Dengan demikian, dalam pandangan teori konflik, sesungguhnya perubahan atau konflik sosial bersumber dari internal masyarakat itu sendiri. Hal inilah yang tidak diperlihatkan oleh pendekatan struktur fungsional. Bertolak dari pendekatan-pendekatan di atas, dapat dikatakan bahwa konflik sosial sulit dihindari. Yang dapat dilakukan adalah bagaimana mengendalikan konflik-konflik yang timbul sehingga tidak mengarah kepada bentuk-bentuk kekerasan. Ralf Dahrendorf, sebagaimana dikutip Nasikun, menyebutkan tiga cara sebagai upaya untuk mengendalikan konflik sosial yang terjadi. Pertama, konsiliasi. Konsiliasi ini terwujud melalui lembaga-lembaga yang memungkinkan tumbuhnya pola diskusi dan pengambilan keputusan di antara pihakpihak yang terlibat dalam konflik mengenai persoalan yang sedang dipertentangkan. Kedua, mediasi. Dalam mediasi, pihak-pihak yang bersengketa sepakat untuk menunjuk pihak ketiga yang akan memberikan nasihat tentang bagaimna mereka mengakhiri konfliknya. Ketiga, arbitrasi. Di dalam arbitrasi ini, pihak-pihak yang terlibat konflik sepakat untuk menerima atau terpaksa menerima kehadiran pihak ketiga yang akan memberikan keputusan tertentu untuk menyelesaikan konflik di antara mereka. ${ }^{13}$

\section{Menuju Integrasi Nasional}

Konflik dan integrasi adalah dua variabel yang sangat berkaitan. Makin tinggi tingkat konflik atau pertentangan dalam sebuah kelompok, maka makin rendah tingkat integrasinya. Demikian antara lain pendapat Ogbun dan Nimkoff sebagaimna dikutip oleh Astrid S. Susanto. ${ }^{14}$ Lebih lanjut Astrid menjelaskan beberapa standar keberhasilan integrasi yang mencakup: (1) bila anggota masyarakat merasa bahwa mereka berhasil mengisi kebutuhan satu sama lain; (2) bila tercapai semacam konsensus mengenai norma-norma dan nilai-nilai sosial; (3) bila norma-norma cukup lama konsisten dan tidak berubah-ubah. ${ }^{15}$

Memperhatikan standar-standar ini, diperlukan titik temu dan konsensus sebanyak mungkin untuk menghadapi pertentangan. Titik temu itu akan dapat dijumpai pada setiap perbedaan bagi etnis, budaya,

\footnotetext{
${ }^{13}$ Nasikun, Sistem Sosial Indonesia, h. 22.

${ }^{14}$ Astrid S. Susanto, Pengantar Sosiologi dan Perubahan Sosial (Binacipta, 1985), h. 103

${ }^{15}$ Astrid S. Susanto, Pengantar Sosiologi, h. 105.
}

Vol. 22 Nomor. 1 Januari 2011 
Pluralitas Indonesia, oleh: Miftahuddir

ras maupun agama. Salah satu yang menyebabkan sulitnya mencari titik temu bagi berbagai perbedaan adalah keinginan salah satu kelompok untuk menguasai kelompok lain. Di samping itu, adanya kecurigaan sosial pada suatu kelompok terhadap kelompok lain juga berperan dalam pengekalan konflik sosial.

Dalam sejarah Indonesia, Sumpah Pemuda menjadi salah satu tonggak penting bagi integrasi bangsa Indonesia di awal abad ke-20. Kesepakatan untuk bertanah air satu, berbangsa satu dan berbahasa satu itu mampu menyatukan langkah penduduk Indonesia menuju kesatuan dan persatuan.

Sayangnya, Sumpah Pemuda lebih banyak bersifat fisik (lahiriah) semata, dan tidak menyentuh pada hal-hal yang oleh teori Struktural Fungsional disebut nilai-nilai umum yang disepakati bersama. Untuk menciptakan integrasi nasional sesungguhnya tidak hanya dengan melakukan kesepakatan atau konsesus yang bersifat lahiriah semata. Lebih dari itu, seringkali konsensus itu dipaksakan sebagaimana tampak pada masa Orde Baru. Kebijakan-kebijakan penguasa Orde Baru seperti kewajiban penerapan asas tunggal bagi parpol dan ormas, dwifungsi ABRI, dan pelaksanaan ideologi pembangunan adalah sebagian dari banyak contoh konsensus yang diterima secara terpaksa. Akibatnya, justru kebijakan itu sendiri memunculkan berbagai konflik yang berkepanjangan dan berujung pada tumbangnya rezim Orde Baru pada tahun $1998 .^{16}$

Banyak konflik yang mengarah pada disintegrasi nasional yang pernah terjadi di Indonesia setelah tumbangnya Orde Baru itu, seperti konflik Islam-Kristen di Maluku, konflik Dayak-Madura di Sampit, Betawi dengan Madura di Jakarta dan konflik-konflik daaerah di Papua dan Aceh. Bahkan pada tingkat paling bawah dalam masyarakat kita juga terdapat konflik laten, yaitu tawuran antarpelajar, antardesa, kelompok sosial tertentu, gengster dan lain-lain. Semua konflik tersebut mengancam sendi-sendi integrasi sosial bangsa Indonesia.

Menurut Soerjono Soekanto, konflik-konflik di dalam masyarakat diakibatkan beberapa hal: (1) kuatnya solidaritas dalam kelompok (in-group); (2) bila pertentangan itu terjadi dalam sebuah kelompok, maka solidaritas kelompok tersebut retak; (2) perubahan

${ }^{16}$ Al-Chaidar, Reformasi Prematur Jawaban Islam Terhadap Reformasi Total (Jakarta: Darul Falah, 1998), h. 30. 
Pluralitas Indonesia, oleh: Miftahuddin

mental dan kepribadian orang yang disebabkan oleh situasi pertentangan; (3) hancurnya harta benda dan jatuhnya korban manusia. Hal ini ditimbulkan oleh pertentangan yang sudah mengarah kepada kerusuhan; (4) akomodasi atau dominasi antarpihak yang terlibat konflik. Bila kekuatan kedua pihak seimbang, maka kemungkinan yang terjadi adlah akomodasi. Tetapi bila salah satu pihak takluk kepada pihak yang lain, maka kemungkinan yang terjadi adalah dominasi pihak yang menang terhadap yang kalah. ${ }^{17}$

\section{Tanggapan Islam}

Di antara konflik besar yang sedang mencabik-cabik kesatuan bangsa Indonesia adalah konflik agama dan etnis. Kedua konflik ini menyibukkan para petinggi negara dan aparat keamanan, menguras banyak harta, memakan banyak korban jiwa dan mengancam persatuan dan kesatuan nasional. Bagaimanakah Islam menanggapi konflik semacam ini? Untuk menjawab pertanyaan ini, beberapa ayat al-Qur'an kiranya layak untuk dikemukakan sebagai berikut. Di dalam Qs. alBaqarah [2]: 255, Allah berfirman: "Tidak ada paksaan (untuk memasuki) agama (Islam); sesungguhnya telah jelas jalan yang benar dari jalan yang sesat". Dalam ayat yang lain, yakni Qs. al-Nahl [16]: 125, Allah berfirman: "Serulah (manusia) ke jalan Tuhan-mu dengan cara hikmah dan nasehat yang baik dan bantahlah merka dengan cara yang baik. Dan, dalam Qs.al-Kafirun [109]: 6, Allah berfirman: "Untukmu agamamu dan untukku agamaku."

Ayat-ayat di atas menjelaskan bahwa konsep beragama adalah fanatik ke dalam dan toleran keluar. Fanatisme ke dalam menghasilkan semangat menjalankan agama yang kuat dengan metode pemahaman yang otentik. Sedangkan toleransi keluar menciptakan suasana keberagman yang damai dan kondusif. Masing-masing agama memiliki ajaran tentang dakwah (penyebaran agama). Yang diperlukan lalu adalah membuat aturan yang sesuai dengan kesepakatan antarpenganut agama. Hal itu bertujuan agar tidak terjadi benturan-benturan selama menjalankan misi suci tersebut. Kerukunan antarumat beragama tidak boleh dengan peleburan dan pelarutan ajaran agama yang satu dengan agama yang lain atau dengan menganggap semua agma sama atau boleh

\section{h. 226 .}

${ }^{17}$ Soerjono Soekanto, Sosiologi Suatu Pengantar (Jakarta: UI-PRESS, 1981),

Vol. 22 Nomor. 1 Januari 2011 
mengikuti ritual keagamaan agama lain. Selain itu, Islam juga mengajarkan penghormatan kepada semua manusia, baik sebagai tetangga maupun saudara sebangsa dan senegara.

Tidak hanya keragaman agama, al-Qur'an juga member tuntutan tentang keragaman etnis. Hal ini bias dibaca, misalnya, dalam firman Allah: Hai manusia, sesungguhnya Kami menciptakan kamu dari seornag laki-laki dan seorang perempuan dan menjadikan kamu berbangsa-bangsa dan bersuku-suku supaya kamu saling ta'aruf (kenalmengenal). Sesungguhnya orang yang paling mulia diantara kamu disisi Allah adalah yang paling bertaqwa. (Qs. al-Hujurat [49]: 12). Ayat ini menunjukkan bahwa keragaman etnis tidak boleh dilihat dari segi perbedaannya semata. Keragaman harus dilihat pula dari persamaan dan peluang saling membutuhkan serta ketergantungan antara yang satu dengan yang lain. Semua itu ditempuh dengan ta 'aruf (saling mengenal dan memahami) dengan segala cara dan sarana yang tersedia. Bila pembicaraan mengenai etnis hanya berkisar pada kemandiriannya semata, maka kebinekaan itu menjadi modal perpecahan. Namun bila dibicarakan pula tingkat kesamaan derajat sebagai sesama manusia serta ketergantungannya kepada etnis lain, maka yang muncul kemudian adalah sikap saling menghormati, tidak saling mencurigai, pentingnya belajar dari etnis lain dan sebagainya.

Kiranya konsep Islam dalam menjaga dan menciptakan kerukunan antaragama dan etnis ini perlu terus dikaji untuk dapat diterapkan sebagai alternatif yang vital. Nurcholis Madjid mengatakan sebagai berikut: "Jadi pluralisme tidak dapat dipahami hanya dengan mengatakan bahwa masyarakat kita adalah majemuk, beraneka ragam, terdiri dari berbagai suku dan agama, yang justru hanya menggambarkan kesan fragmentasi. Pluralisme juga tidak dapat difahami sekedar sebagai kebaikan negative (negative good), hanya ditilik dari kegunaannya untuk menyingkirkan fanatissme (to keep fanaticsm at bay). Pluralisme harus difahami sebagai "pertalian sejati ke-bhinekaan dalam ikatan-ikatan keadaban" (genuine engagement of difersities within the boods of civility)" ${ }^{18}$ Dia juga mengatakan bahwa

\footnotetext{
${ }^{18}$ Nurcholis Madjid, Cendekiawan \& Religiusitas Masyarakat (Jakarta: Paramadina, ), h. 63.
} 
Pluralitas Indonesia, oleh: Miftahuddin

pluralisme terkait erat dengan toleransi dan toleransi adalah salah satu asas masyarakat madani. ${ }^{19}$

\section{Penutup}

Telah diketahui bahwa struktur masyarakat Indonesia sangat beragam. Pluralitas yang bersifat multi-dimensional itu menjadi persoalan tersendiri bagi bangsa yang besar ini. Untuk itu, diperlukan adanya good will dari semua elemen masyarakat untuk membangun bangsa ini dengan baik dan mempertahankan kesatuan dan persatuan negara ini, meskipun dengan harga yang sangat mahal sekalipun. Konflik-konflik antar etnis dan antara agama terbukti menumbuh suburkan sparatisme regional, memperberat beban mental bangsa, menambah besar pengeluaran pembiayaan pemerintah dan masyarakat.

\footnotetext{
${ }^{19}$ Nurcholis Madjid, Cendekiawan \& Religiusitas Masyarakat, h. 64.
} 
Pluralitas Indonesia, oleh: Miftahudd1

\section{Daftar Pustaka}

Al-Chaidar, Reformasi Prematur Jawaban Islam Terhadap Reformasi Tatal, Jakarta: Darul Falah, 1998.

Departemen Agama Republik Indonesia, Al-Qur'an dan Terjamahnya, Jakarta: Pelita IV Tahun I 1984.

Geertz, Hildred, Aneka Budaya Dan Komunikasi Di Indonesia, Jakarta: Yayasan Ilmu-Ilmu Sosial, 1981.

Johnson, Doyle Paul, Teori Sosiologi Klasik dan Modern, Jilid 2, Jakaarta: Gramedia Pustaka Utama, 1990.

Nasikun, Sistem Sosial Indonesia, Jakarta: Rajawali Pers, 1995.

Nurcholis Madjid, Cendekiawan dan Religiusitas Masyarakat, Jakarta: Paramadina, 1999.

Soekanto, Sarjono, Sosiologi Suatu Pengantar, Jakarta: UI-PRESS, 1981.

Susanto, Phil Astrid S, Pengantar Sosiologi dan Perubahan Sosial, Binacipta, 1985.

Th. Sumartana, dkk. Pluralisme, Konflik dan Pendidikan Agama Di Indonesia, Yogyakarta: Interfidei. 